\title{
DEVELOPMENT OF AGRICULTURAL FARMS IN TERMS OF COMMON AGRICULTURAL POLICY SUPPORT IN THE OPINION OF FARMERS
}

Slawomir Zawisza ${ }^{1}$, Dr. hab., Prof.; Piotr Prus ${ }^{2}$, PhD and Szymon Beben ${ }^{3}$, M.Sc. 1,2,3 UTP University of Science and Technology in Bydgoszcz, Poland

\begin{abstract}
The rural areas are a place of living and work of much of the society and agricultural production is essential for the Polish national economy. The aim of this paper has been to determine the prospects for the development of agricultural family farms. With that in mind, an important aspect has been to diagnose the opinions of the farmers on the key sources of income, benefiting from the CAP support, the recent investment projects completed, opinions on changes in the operation of agriculture after the integration with the EU, its impact on the development potential of the farms under study as well as plans for the farms. The research material was acquired from the surveys made in 2018 which included 60 respondents residing in the Zlawies Wielka commune. The survey research has demonstrated that a great majority of the respondents were living mostly from agricultural production, only some used other support than direct payments. Less than half of the respondents were making efforts to develop their farms through the investments made over the recent years. The farmers planned handing over the farm to their successors or continuing the work themselves.
\end{abstract}

Key words: agriculture, agricultural farm, the European Union, Common Agricultural Policy. JEL code: D21, O10, Q10, Q12, Q18, Q19.

\section{Introduction}

The Common Agricultural Policy is the oldest and the most comprehensive community policy of the European Union and one of the pillars of the European integration (Bardaji I., et. al., 2009, Potter C., Tilzey M., 2005). To a great extent, it determines the operation of the agricultural sector and the situation of the rural areas of the EU member states (Piorr A., Viaggi D., 2015, SantiagoFreijanes J.J., et. al., 2018, Van de Poele L., 2015, Vlahos G., Louloudis L., 2011). The CAP determines the principles of homogenous operation, protection of and assistance to the agricultural sector in the EU member states. The CAP key objectives include the agricultural market stability, multi-functional development of the rural areas, supporting investments to diversify the operation of the agricultural farms (Benjamin C., 1994, Galluzzo N., 2017), and providing the farmers with an adequate income and living conditions. Poland's joining the European Union has created new opportunities of solving many economic and social problems (compare Kalinowski S., 2018). It is true for every sector of the Polish economy, especially agriculture (Kielbasa B., Grzelak A., 2014).

Poland's membership in the European Union has changed the economic conditions of Polish agriculture management (Chrzanowska M., 2017, Gazinski B., 2016, Kisiel R., Marks-Bielska R., 2007, Marks-Bielska R., et. al., 2011, Piecuch J., Paluch L., 2018). Prior to Poland's joining the EU, the national budget support for agriculture was inconsiderable, and in the first years of the transformation, namely in the 1990s, it hardly existed. The agricultural policy was changing too frequently and it was not part of any comprehensive long-term strategy, which limited its efficiency and effectiveness. Prior to the referendum on Poland's joining the European Union there were concerns how the rural voters would vote as the rural areas were in a difficult situation after the transformations initiated in 1989. A considerable group of the farmers were afraid of competition from imports of foreign food, which could, in their opinion, result in bankruptcy of many agricultural farms, dairies and meat processing plants, to mention just a few. On the one hand, the prospect of Poland's EU membership triggered concerns of a possible failure of the Polish agrifood market,

\footnotetext{
${ }^{1}$ Corresponding author. E-mail address: piotr.prus@utp.edu.pl
} 
however, on the other hand, it gave hope to the farmers for higher payments for agricultural production and for a greater stability of production conditions and marketing (Borys B., Slosarz P., 2003). The concerns were being eliminated with difficulty and Euro-enthusiasts were bigger and bigger in number together with direct payments and the CAP financial programmes. Interestingly, the process of Poland's integration with the European Union enhanced the volume of agricultural produce and incomes generated from it, an increase in income from the entire agricultural sector would not be possible without a considerable increase in CAP payments (Poczta W., et. al., 2012).

The evolution of agrarian systems in the countries with a fragmented land structure, including Poland, leads to a decreasing number of agricultural farms and an increase in acreage and effectiveness of enterprises developing their business. Next to the Common Agricultural Policy instruments being implemented, also the local factors show much impact on the changes (Wojewodzic T., et. al., 2017). A possibility of benefiting from the pre-accession funds and a prospect of EU membership became a strong trigger to develop new institutional frameworks to introduce a new type of agricultural policy and the system of supporting the development of rural areas and agrifood processing modernisation in Poland. A very fast launch of direct payments must be considered a success of the first months of the EU membership. In the rural areas the spirits got higher, optimism and support for Poland's integration with the European Union got definitely enhanced (Roman M., Roman M., 2018).

Despite visible deficiencies in some sectors, one must state that Poland's joining the EU and the Polish agriculture being covered by the CAP instruments have changed the conditions of agriculture operation significantly (Piecuch J., Paluch L., 2018, Roman M., Nuszkiewicz K., 2013). The membership in the European Union structures translates into an almost unlimited access to a vast consumer market, which is especially important for agricultural producers; it creates new opportunities of generating income due to the EU market size and CAP subsidies.

The aim of the study has been to diagnose the farmers' key sources of income and to evaluate using EU programmes for development-enhancing investments on farms. There was also estimated the percentage of the farms keeping their accounts and the source of accounting assistance. The investment projects executed in the last 4 years have been diagnosed and the opinions of the respondents on a change in the situation of farms upon Poland joining the EU and the forecast of that situation for the successive 2 years have been provided.

\section{Material and the research method}

To verify the key assumptions of the paper, own survey research was performed. The survey covered 60 farmers from agricultural farms of various village administrations of the Zlawies Wielka commune. 15 people refused to take part. The survey was made from 22 to 24 June 2018.

The commune is found in the kujawsko-pomorskie province, in the Torun county, between Bydgoszcz and Torun, and it covers the area of 17753 ha with the population of 13786, with 10195 people of legal age. In 2017402 persons were registered as unemployed, including 79 people entitled to unemployment benefits. The commune's agricultural land accounts for $64 \%$ of the total area, while woodland, most of which constitutes preserved landscape, accounts for $26 \%$. It is common knowledge that the Zlawies Wielka commune is typically agricultural (Gmina..., 2018).

In the Zlawies Wielka commune, most respondents running agricultural farms were men (60\%), whereas women accounted for $40 \%$. Of all the respondents, $46.7 \%$ were people aged $41-55,23.3 \%$ - aged 56-65 and people aged 65 (6.7\%). The persons below 40 years of age accounted for more 
than $23.3 \%$. Most of the farmers surveyed had a vocational education background $(63.0 \%)$, while $24.0 \%$ - secondary school background, and $10.0 \%$ - higher education background. The lowest percentage $(3.0 \%)$ of the respondents had a primary school background only. Among the respondents only $20.0 \%$ declared their willingness to enhance their qualifications. In the Zlawies Wielka commune, most farms fell within the range from 10 to 14.99 ha (43.3\%), many farms from 20 to 50 ha (30.0\%) and 15 to 19.99 ha (13.3\%), whereas many fewer - from 5.0 to 9.99 ha $(6.8 \%)$ and from 2.0 to 4.99 ha (3.3\%). The survey included 2 people $(3.3 \%)$ with a farm more than 50 ha in size.

\section{Research results and discussion}

Various strategies of income diversification make it possible for the farmers to deal with changing conditions in a changing economic situation better (Pacin F., Oesterheld M., 2014, Weltin M., et. al., 2017). The farms which run additional business on top of the traditional agriculture and are diversified enough to generate income from two or more types of business activity have a chance for a greater stability from increased incomes (Barnes A. P., et. al., 2015, Edmond H., Crabtree J. R., 1994, Northcote J., Alonso A. D., 2011). The results show that $86.6 \%$ of the respondents claimed that agricultural production was as the main source of income. Only $6.7 \%$ said they were working outside the farm. Also $6.7 \%$ of the respondents claimed having both income variants at the same time. As for the types of work outside the farm, working at school, in the library and in the offices of public authorities were most frequently listed (Fig. 1). Unfortunately, none of the respondents claimed running a non-agricultural business activity. The potential of the strategy much depends on the availability of the capital on a given farm. For that reason non-agricultural employment is often the most available strategy not only to ensure the household income but also to supplement the income required to keep the farm running (Meert H., et. al., 2005). The information acquired from the respondents shows that only $16.7 \%$ of the respondents benefited from the EU assistance other than direct payments (Fig. 2), which could have been also the reason of a lack of interest in nonagricultural business activity which often requires making necessary investments (Nguyen T. H. T., et. al., 2016, Reardon T., et. al., 2000).

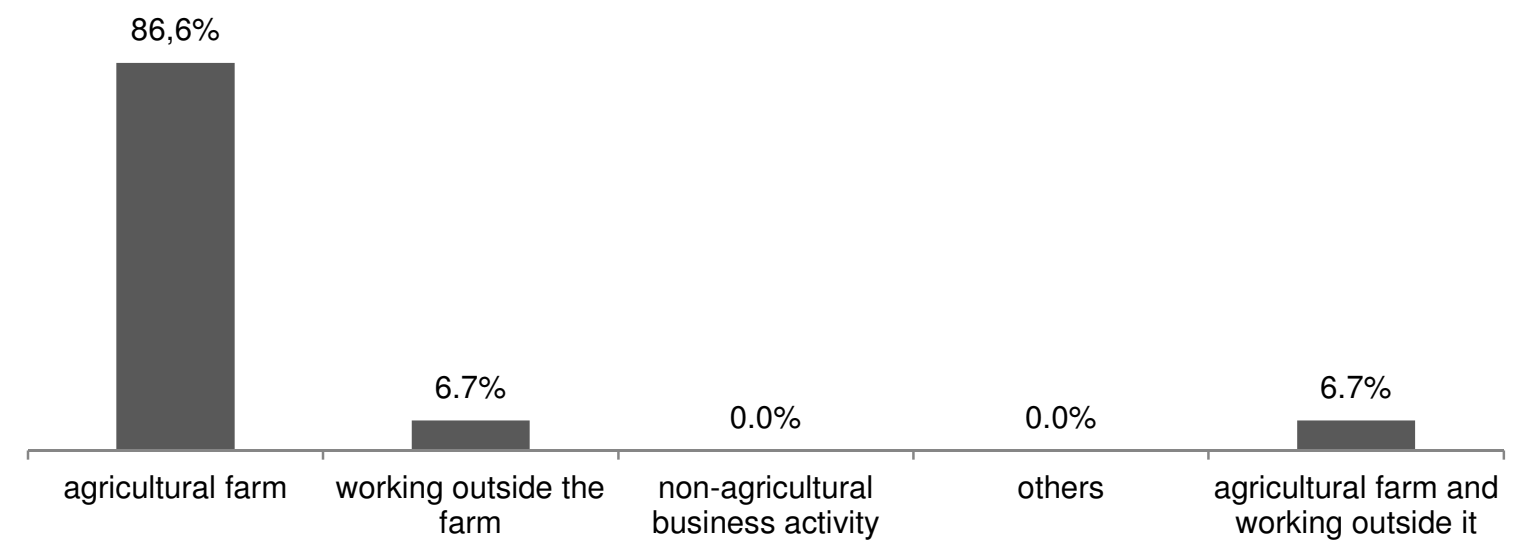

Source: author's calculations based on research

Fig. 1. Main source of income 


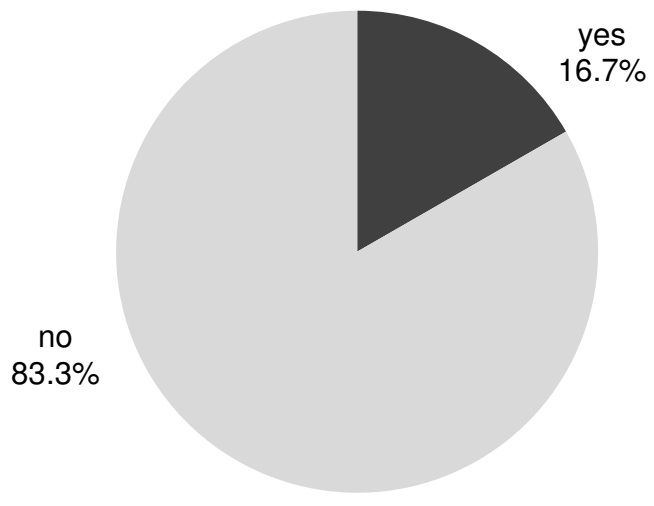

Source: author's calculations based on research

Fig. 2. Benefiting from the EU financial support other than direct payments

For an effective agricultural farm management, book-keeping is helpful as it facilitates recording information on what is history and what happens on farms, which provides the grounds for defining the objectives and tasks, methods and means of executing them, it is the condition for the right judgements, decisions, and effective farm management (Rozanska E., 2015). With the data acquired in the survey, only $43.3 \%$ of the persons were book-keeping on their farm, with $29.9 \%$ bookkeeping on their own, and $6.7 \%$ using the assistance of the specialist or friends (Fig. 3 ).

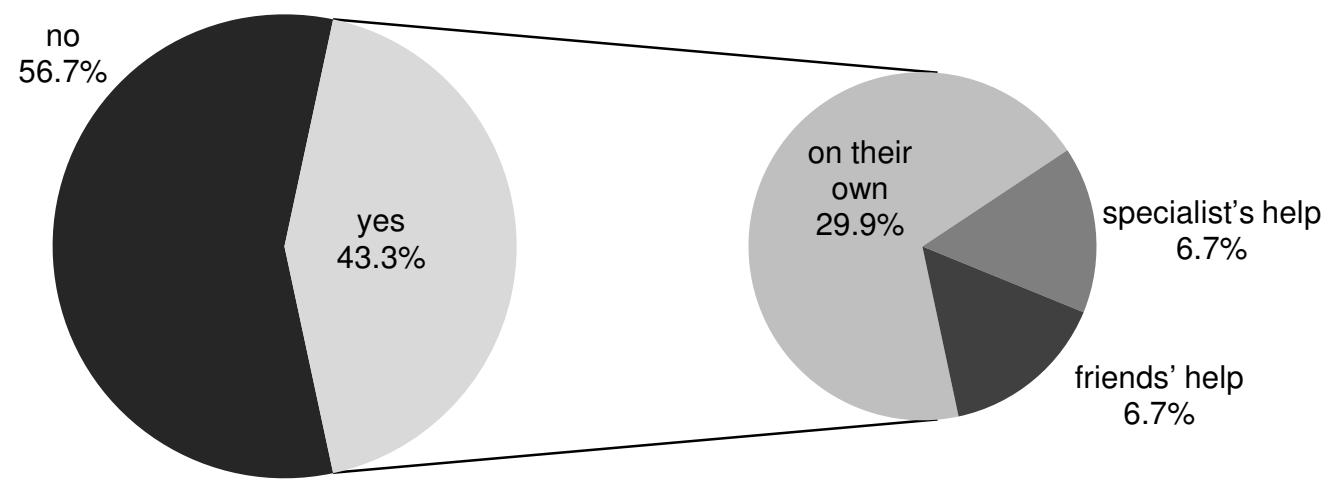

Source: author's calculations based on research

Fig. 3. Book-keeping

The research performed in the Zlawies Wielka commune shows that over the last 4 years more than PLN 50000 has been invested in own farm; $43.3 \%$ respondents. Most frequently the purchase of machinery and equipment (38.9 \%) and the modernisation of farm buildings (33.3 \%) were financed. Slightly less (22.2\%) was allocated to field works machinery, whereas $5.6 \%$ - to the purchase of land and the construction of manure storage pads and surface hardening (Fig. 4). 


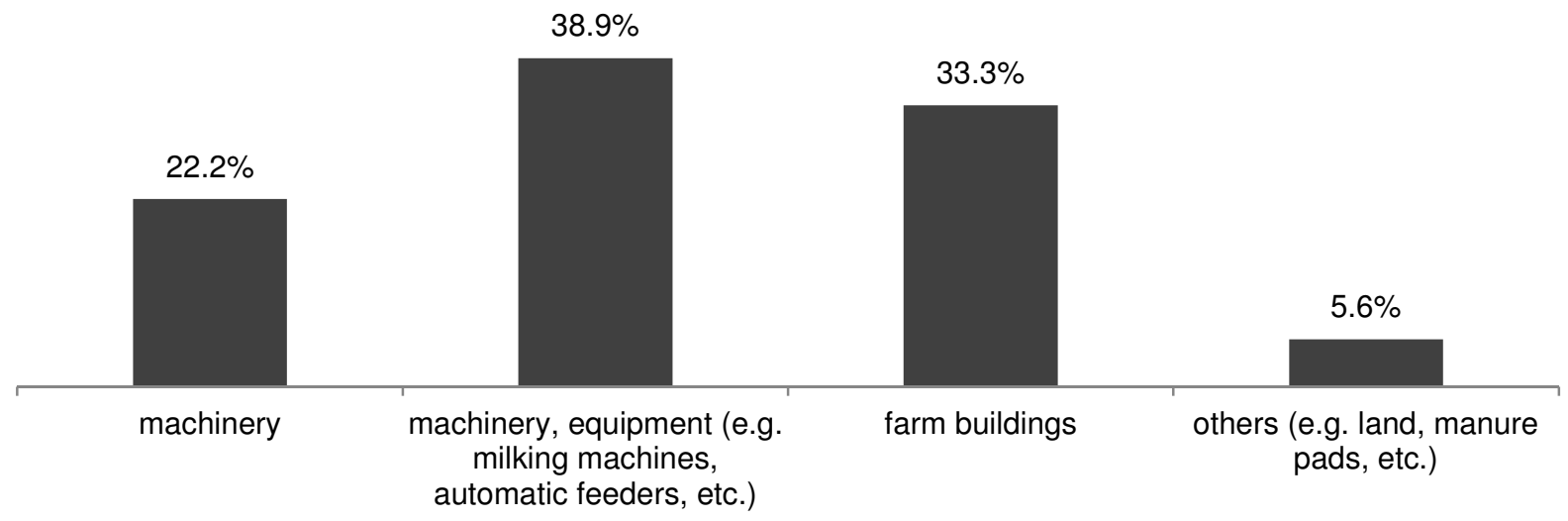

Source: author's calculations based on research

Fig. 4. Investment projects completed over the last four years

Most of the respondents claimed that Poland's joining the European Union enhanced the situation of the farm (43.3\%), while $20.0 \%$ claimed the opposite, and $26.7 \%$ of the respondents did not express their opinion, and the lowest number of the respondents $(10.0 \%)$ claimed that joining the EU did not change the situation on the farm (Fig. 5).

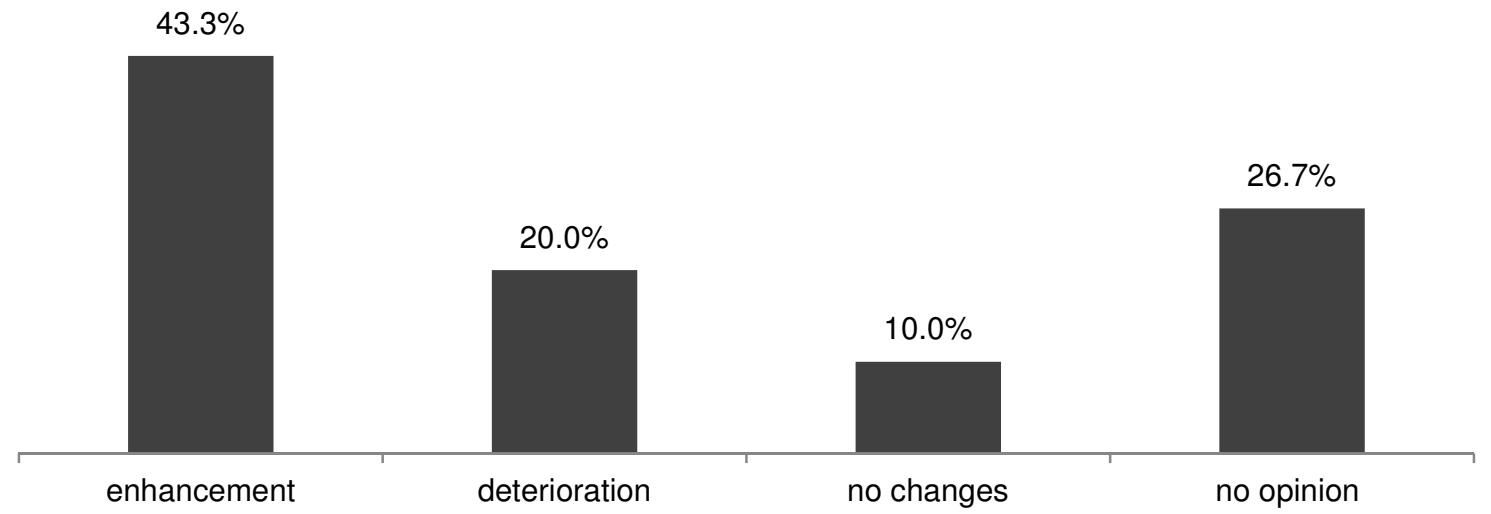

Source: author's calculations based on research

Fig. 5. Change in the farm's situation upon Poland's joining the European Union

In the countries of Central and Eastern Europe, already for a few years after joining the European Union the dynamic processes of structural changes are reported, including a decrease in the number of small agricultural farms. The tendencies are appreciated, however the fact is disregarded that some farms give up agricultural production officially only, and the arable land, especially in the regions with land fragmentation, is held by the units which still recently have been production entities, which can be due to Central and Eastern Europe-specific historic, cultural and institutional conditions and the economic calculation, including the land owners pursuing economic rents, including area payments (Satola L., et. al., 2018). Most of the respondents claimed that running a farm without assistance from the European Union would not be cost-effective (43.3\%). Another opinion was expressed by $26.7 \%$ of the respondents, and $30.0 \%$ did not express any opinion. Most of the respondents did not have any definite opinion on the prospective situation of their farm in 2 years $(43.3 \%) ; 20.0 \%$ of the respondents claimed that the situation will deteriorate or it will remain unchanged. Only $16.7 \%$ expected an improvement in the situation of their farm (Fig. 6). A longtime persistence of unfavourable costs-to-production relation on the farm for a long time triggers some concern as it can lead to progressive decapitalisation of the property and disregarding the remuneration for own work, which, sooner or later, poses a threat of the farm's economic failure. 
The situation where, for a positive financial result, one must acquire external funds (subsidies, payments), is especially dangerous in terms of the EU Common Agricultural Policy changes planned. The payments and subsidies limitations planned can lead to a serious crisis in the sector as a considerable part of the entities will not be able to run their business in a way as to generate the production surplus over costs (Satola L., et. al., 2014).

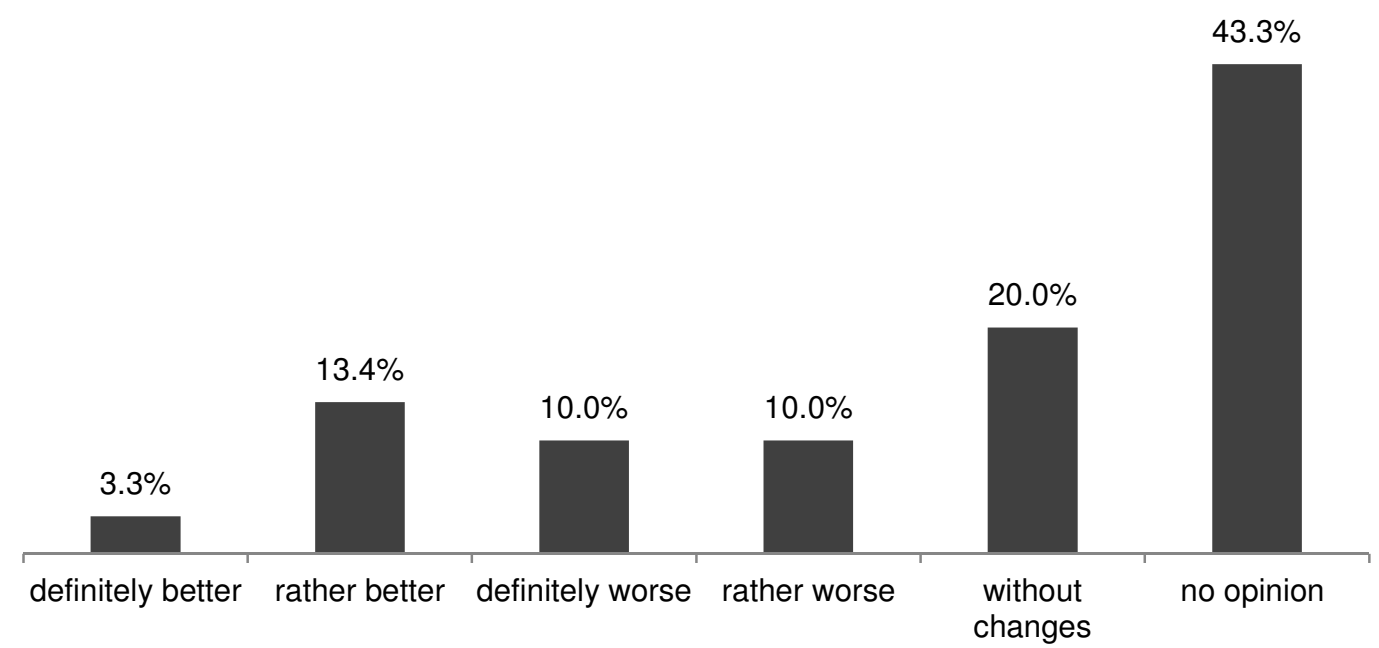

Source: author's calculations based on research

Fig. 6. Forecast situation on the farm in 2 years

The analysis of the plans for their farms declared by the respondents were interesting. Most respondents ( $46.7 \%$ ) planned to hand over the farm to a family member (mostly children) in the future. Selling it was declared by $10.0 \%$, while more than $16.7 \%$ wanted to keep on managing it, of which $5.0 \%$ did not intend to make any changes in the acreage, whereas $11.7 \%$ planned to increase the acreage. Every fourth person (26.6 \%) did not have any precise farm management plans.

\section{Conclusions}

1) A vast majority of the respondents claimed that agricultural production was their key source of income. Some also combined it with being a hired labourer outside their own farm. Unfortunately, No interest in non-agricultural business activity was recorded.

2) As for benefiting from the CAP funds, direct payments prevailed. Other forms of assistance to agriculture were hardly indicated.

3) Almost half of the farmers surveyed were running their agricultural book-keeping, which facilitated a more effective farm management.

4) Almost half of the agricultural farm owners made substantial investments on their farms, trying to modernise both the farm buildings and the machinery.

5) Most farmers believed that Poland's joining the European Union enhanced the situation of their farm.

6) The farmers planned to hand over the farm or declared to keep on working further on the farm, which can suggest that the prospect of developing their farms and the agricultural sector in Poland is seen as positive.

7) Interestingly, due to the scope of research, the results cannot be generalised. The considerations provided in this paper concerning the results analysis only refer to a relatively inconsiderable, as compared to the entire community, group of farmers. For that reason the paper is a diagnosis, 
which covers only a certain group of respondents, and the reader should not treat the results as representative for all the agricultural farm owners.

\section{Bibliography}

1. Bardaji, I., Iraizoz, B., \& Rapun, M. (2009). The Effectiveness of the European Agricultural Quality Policy: a Price Analysis. Spanish Journal of Agricultural Research, 7(4), pp. 750-758.

2. Barnes, A. P., Hansson, H., Manevska-Tasevska, G., Shrestha, S. S., Thomson, S. G. (2015). The Influence of Diversification on Long-term Viability of the Agricultural Sector. Land Use Policy, 49, 404-412.

3. Benjamin, C. (1994). The Growing Importance of Diversification Activities for French Farm Households. Journal of rural studies, 10 (4), 331-342.

4. Borys, B., Slosarz, P. (2003). A Note on the Opinions of Farmers from Lowland Regions of Poland Concerning Factors Affecting the Operation of their Family Farms on the Threshold of Accession to the EU. In Livestock Farming Systems in Central and Eastern Europe. Wageningen Academic Publishers, Wageningen, pp. 215-221.

5. Edmond, H., Crabtree, J. R. (1994). Regional variation in Scottish pluriactivity: The Socio-economic Context for Different Types of Non-farming Activity. Scottish Geographical Magazine, 110 (2), 76-84.

6. Galluzzo, N. (2017). The Development of Agritourism in Romania and Role of Financial Subsidies Allocated under the Common Agricultural Policy. Geographia Polonica, 90(2), pp. 25-39.

7. Gazinski, B. (2016). Poland Recast. Agriculture and Rural Development during a Period of the Transformation and European Integration. An Overview. Agrolife Scientific Journal, 5(1), pp. 69-82.

8. Chrzanowska, M. (2017). Multidimensional Comparative Analysis of the Polish Agri-Food Sector in Regard to other EU Countries in the Years 2004-2014. Proceedings of the International Conference "Economic Science for Rural Development", Jelgava, Latvia, No. 44, pp. 323-329.

9. Gmina Zlawies Wielka (Zlawies Wielka Commune) (2018). Retrieved: https://www.powiattorunski.pl/8056,gm-zlawies-wielka. Access: 19.04.2018.

10. Kalinowski, S. (2018). The Working Poor in the European Union. Proceedings of the International Scientific Days 2018 "Towards Productive, Sustainable and Resilient Global Agriculture and Food Systems", Nitra, Slovak Republic, pp. 977-991.

11. Kielbasa, B., Grzelak, A. (2014). Assessment Of The Use Of The European Union Funds To Support Investments On Polish Farms In The Regional Perspective. Acta Scientiarum Polonorum: Oeconomia, 13(2), pp. 49-61.

12. Kisiel, R., Marks-Bielska, R. (2007). Polish Rural Areas and Agriculture in the Aspect of Globalization. Proceedings of the 3rd International Scientific Conference on Rural Development, Kaunas, Lithuania, pp. 62-66.

13. Marks-Bielska, R., Babuchowska, K., Nazarczuk, J. M. (2011). Polish Countryside and Agriculture on the Background of Global Changes. Proceedings of the 5th International Scientific Conference on Rural Development - In Global Changes, Kaunas, Lithuania, pp. 44-48.

14. Meert, H., Van Huylenbroeck, G., Vernimmen, T., Bourgeois, M., Van Hecke, E. (2005). Farm Household Survival Strategies and Diversification on Marginal Farms. Journal of rural studies, 21(1), 81-97.

15. Northcote, J., Alonso, A. D. (2011). Factors Underlying Farm Diversification: the Case of Western Australia's Olive Farmers. Agriculture and Human Values, 28(2), 237-246.

16. Nguyen, T. H. T., Tran, V. T., Bui, Q. T., Man, Q. H., de Vries Walter, T. (2016). Socio-economic Effects of Agricultural Land Conversion for Urban Development: Case Study of Hanoi, Vietnam. Land Use Policy, 54, 583-592.

17.Pacin, F., Oesterheld, M. (2014). In-farm Diversity Stabilizes Return on Capital in Argentine Agroecosystems. Agricultural systems, 124, 51-59.

18. Piecuch, J., Paluch, L. (2018). The Evolution of the Agricultural Sector in Central and East European Countries after 12 Years of Membership in the EU on the Example of Poland. Proceedings of the International Conference "Economic Science for Rural Development", Jelgava, Latvia, No. 47, pp. $238-248$.

19. Piorr, A., Viaggi, D. (2015). The Spatial Dimension of Public Payments for Rural Development: Evidence on Allocation Practices, Impact Mechanisms, CMEF Indicators, and Scope for Improvement. Ecological Indicators, 59, pp. 1-5.

20. Potter, C., Tilzey, M. (2005). Agricultural Policy Discourses in the European Post-Fordist Transition: Neoliberalism, Neomercantilism and Multifunctionality. Progress in Human Geography, 29 (5), 581-600.

21. Poczta, W., Pawlak, K., Czubak, W. (2012). Production and Income Situation in Polish Agriculture after Accession to the European Union. Berichte uber Landwirtschaft, 90(1), pp. 133-158.

22. Reardon, T., Taylor, J. E., Stamoulis, K., Lanjouw, P., Balisacan, A. (2000). Effects of Non-farm Employment on Rural Income Inequality in Developing Countries: an Investment Perspective. Journal of Agricultural Economics, 51(2), pp. 266-288.

23. Roman, M., Nuszkiewicz, K. (2013). Changes in Agricultural Production in Poland after Accession to the European Union. Zeszyty Naukowe Szkoly Glownej Gospodarstwa Wiejskiego w Warszawie. Problemy Rolnictwa Swiatowego, 13(4), pp. 156-161. 
24. Roman M., Roman M. (2018). The Similarity of the Structure of Foreign Trade in Dairy Products in the European Union. Proceedings of the 27 International Scientific Conference Agrarian Perspectives XXVII. Food Safety - Food Security, Czech University of Life Sciences, Prague, pp. 297-303.

25. Rozanska, E. (2015). Korzysci z prowadzenia rachunkowosci w gospodarstwie rolnym (Benefits of Accounting on an Agricultural Holding). Poradnik Gospodarski, 01, pp. 26-27.

26. Santiago-Freijanes, J.J., Pisanelli, A., Rois-Diaz, M., Aldrey-Vazquez, J.A., Rigueiro-Rodriguez, A., Pantera, A., Vityi, A., Lojka, B., Ferreiro-Dominguez, N., Mosquera-Losada, M.R. (2018). Agroforestry Development in Europe: Policy Issues. Land Use Policy, 76, pp. 144-156.

27.Satola, L., Wojewodzic, T., Dacko, M. (2014). Do Divestments and Investments Determine Farm Development? Bulgarian Journal of Agricultural Science, 20(6), pp. 1281-1288.

28. Satola, L., Wojewodzic, T., Sroka, W. (2018). Barriers to Exit Encountered by Small Farms in Light of the Theory of New Institutional Economics. Agricultural Economics, 64(6), pp. 277-290.

29.Van de Poele, L. (2015). Rural Development from the Grassroots: Twenty Years of the EU "Leader Approach". In Constructing a New Framework for Rural Development. Emerald Group Publishing Limited, Bingley, pp. 195-207.

30. Vlahos, G., Louloudis, L. (2011). Landscape and Agriculture under the Reformed Common Agricultural Policy in Greece: Constructing a typology of interventions. Geografisk Tidsskrift-Danish Journal of Geography, 111(2), pp. 131-147.

31. Weltin, M., Zasada, I., Franke, C., Piorr, A., Raggi, M., Viaggi, D. (2017). Analysing Behavioural Differences of Farm Households: An example of income diversification strategies based on European farm survey data. Land use policy, 62, 172-184.

32. Wojewodzic, T., Sroka, W., Plonka, A. (2017). Local Conditions of Production and Economic Disagrarization of Farms. Proceedings of the 8th International Scientific Conference Rural Development 2017: Bioeconomy Challenges, Aleksandras Stulginskis University, pp. 1400-1404. 